OPEN ACCESS

Citation: Andriy Novikov, Mariia SupNovikova, Clemens Pachschwöll (2020) Stellaria ruderalis M. Lepší, P. Lepší, Z. Kaplan et P. Koutecký, a new species record for the flora of Ukraine. Webbia. Journal of Plant Taxonomy and Geography 75(2): 355-358. doi: 10.36253/jopt9613

Received: August 20, 2020

Accepted: September 15, 2020

Published: November 18, 2020

Copyright:@2020Andriy Novikov, Mariia Sup-Novikova, Clemens Pachschwöll. This is an open access, peer-reviewed article published by Firenze University Press (http://www.fupress.com/webbia) and distributed under the terms of the Creative Commons Attribution License, which permits unrestricted use, distribution, and reproduction in any medium, provided the original author and source are credited.

Data Availability Statement: All relevant data are within the paper and its Supporting Information files.

Competing Interests: The Author(s) declare(s) no conflict of interest.

Editor: Lia Pignotti \& Riccardo M. Baldini

\section{Stellaria ruderalis M. Lepší, P. Lepší, Z. Kaplan et P. Koutecký, a new species record for the flora of Ukraine}

\author{
Andriy Novikov ${ }^{1, *}$, Marita Sup-Novikova ${ }^{2}$, Clemens Pachschwöll 3 \\ ${ }^{1}$ Department of Biosystematics and Evolution, State Museum of Natural History, Nation- \\ al Academy of Sciences of Ukraine, Teatralna str. 18, 79008 Lviv, Ukraine \\ ${ }^{2}$ Ukrainian Catholic University, Stryiska str. 29A, 79000 Lviv, Ukraine \\ ${ }^{3}$ Department of Botany and Biodiversity Research, University of Vienna, Rennweg 14 \\ 1030 Wien, Austria \\ ${ }^{\star}$ Corresponding author. Email: novikoffav@gmail.com
}

\begin{abstract}
Stellaria ruderalis is an annual (semi)ruderal species from the S. media group, which has been recently published by Lepší et al., therefore, its distribution range in Europe is insufficiently known. This paper is based on field exploration of 39 localities of $S$. media s.l. in the Lviv region, Western Ukraine. The first report of S. ruderalis in Ukraine comes from Dmytre village, where it grows at roadsides and arable field edges in a semiruderal habitat of the alliance Aegopodion podagrariae. As only a single population was found, Stellaria ruderalis is obviously still spreading in Western Ukraine, a fact which was reported already for northern Central Europe. This record represents the northeasternmost locality of the species so far known.
\end{abstract}

Keywords: new record, Stellaria media group, Stellaria ruderalis, Ukraine.

\section{INTRODUCTION}

The Stellaria media group comprises in Europe four species, S. media (L.) Vill., S. pallida (Dumort.) Crép., S. neglecta Weihe, and the recently published one, S. ruderalis M. Lepší, P. Lepší, Z. Kaplan et P. Koutecký (Chater and Heywood 1964; Sobey 1981; Lepší et al. 2019). Up to now, S. media, S. pallida, and S. neglecta were recognized for the flora of Ukraine (Klokov 1952; Mosyakin and Fedoronchuk 1999). These species are morphologically close and also overlap in their distribution range. Therefore, either $S$. media s. 1., or more controversially, several microtaxa are reported in the literature (Whitehead and Sinha 1967; Colasante et al. 1999). However, a complex analysis of morphological features (i.e., structure of the inflorescence, length of petals, number of stamens, and shape of tubercules on the seed surface) together with karyological and molecular data allowed distinguishing four species within S. media group in Europe (Lepší et al. 2019).

The newly described $S$. ruderalis is suggested to be an allopolyploid originated from S. pallida and S. neglecta (Lepší et al. 2019), hence it combines 
some morphological features of both species. Stellaria ruderalis differs from $S$. media s. str. by long (longer than wide) conical tubercles on the seed surface with no or few papillae on the upper part of their surface, a more condensed inflorescence at the juvenile stage. Such long tubercules are also present on the seeds of $S$. neglecta. However, S. ruderalis differs from $S$. neglecta by lower number of stamens (3-5(10) vs. 8-10) and shorter petals, which are not longer than sepals. Stellaria pallida distinctly differs from all other species by smaller seeds (up to $1 \mathrm{~mm}$ ), a low number of stamens (1-3, rarely 4), a minute or absent petals, and generally smaller plants. Up to now, Stellaria ruderalis is known from the Czech Republic, Slovakia, Austria, Hungary, Slovenia, Croatia, Serbia, Italy (including Sardinia), and Greece. It grows in disturbed ruderal communities such as grasslands, edges of ruderal scrubs, forests and tree plantations, along roads, railways, and in disturbed river habitats (Lepší et al. 2019). For the Lviv region in Western Ukraine, only S. media (s.l.) is known (Zelenchuk 1991, Sytschak and Kagalo 2010). Therefore, we were interested if Stellaria ruderalis is also occurring in Western Ukraine.

\section{MATERIALS AND METHODS}

Vouchers of Stellaria media s.l. in the herbarium of the State Museum of Natural History of the National Academy of Sciences of Ukraine (LWS) were initially revised. Field work was conducted in May and June 2020 in Lviv and its surroundings. In total, 39 localities of $S$. media s.l. were explored, including 11 localities in Lviv and 28 localities in the adjacent towns and villages (Zymna Voda, Kholodnovidka, Konopnytsia, Dibrivky, Obroshyno, Stavchany, Schyrets, Horbachi, Dmytre, Popeliany, Kaguiv, Dorohovyzh, Rozvadiv, Medenychi, Hirske. Kolodruby, Piatnychiany, Pukenychi, Vilhivtsi, Zaritschia, Nova Skvariava, Griada, Kulykiv, Grusiatychi, Khodorkivtsi, Nestanychi, and Vidnyky). Plants were randomly sampled and identified using a $\times 20$ magnifier. Photos of flowers and seeds were made with a Dino-Lite Pro AM-413ZT digital microscope.

\section{RESULTS AND DISCUSSION}

As expected, no herbarium vouchers of $S$. ruderalis were found in LWS. This can be easily explained with the fact that such a common species group like Stellaria media s.l. is usually neglected by botanists. Among all investigated localities, only one comprised S. ruderalis, where it was growing parapatrically with $S$. media

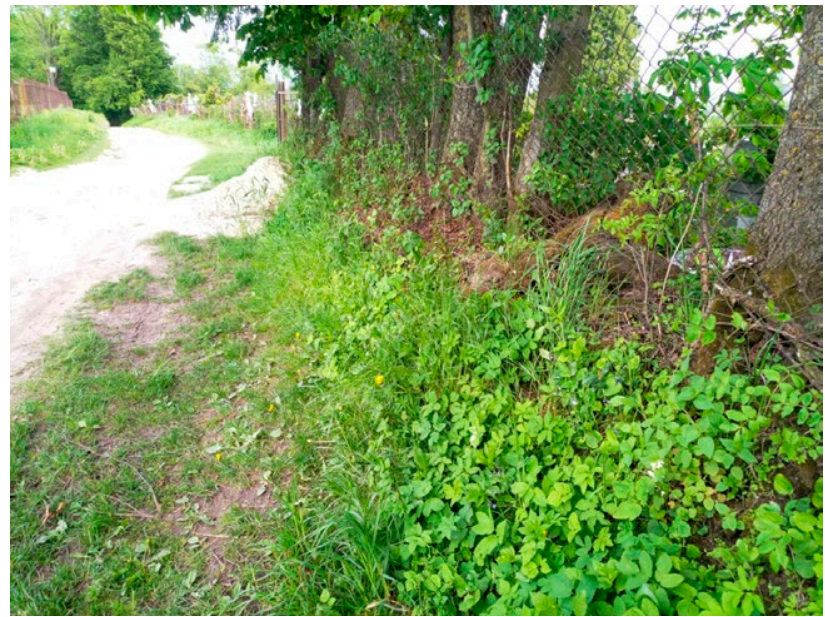

Figure 1. Habitat of Stellaria ruderalis in Dmytre village (Pustomyty district, Lviv region, Ukraine).

s.str. The following herbarium voucher has been deposited in LWS and is available online via http://dc.smnh. org/. Stellaria ruderalis, Ukraine, Lviv region, Pustomyty district, Dmytre village, near the cemetery, $49.60507^{\circ} \mathrm{N}$ $23.87046^{\circ} \mathrm{E}$, alt. $270 \mathrm{~m}$ a.s.l, leg. Andriy Novikov \& Mariia Sup-Novikova 20.05.2020, det. Andriy Novikov 17.06.2020, confirm. Clemens Pachschwöll (LWS 118505). Plants of $S$. ruderalis were growing along both roadsides (Figure 1), at the edge of a arable field and among tree plantings together with Aegopodium podagraria L. (dominant), Cirsium arvense (L.) Scop., Chaerophyllum aromaticum L., Dactylis glomerata L., Lamium album L., Taraxacum officinale agg., Urtica dioica L., and Veronica chamaedrys L. This is a semiruderal and

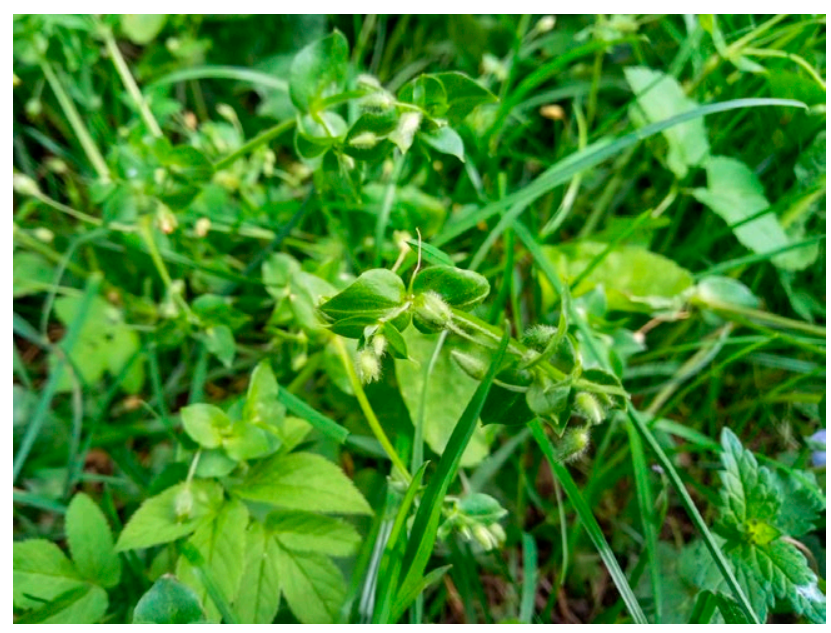

Figure 2. Close-up view of Stellaria ruderalis flowers from Dmytre village. 


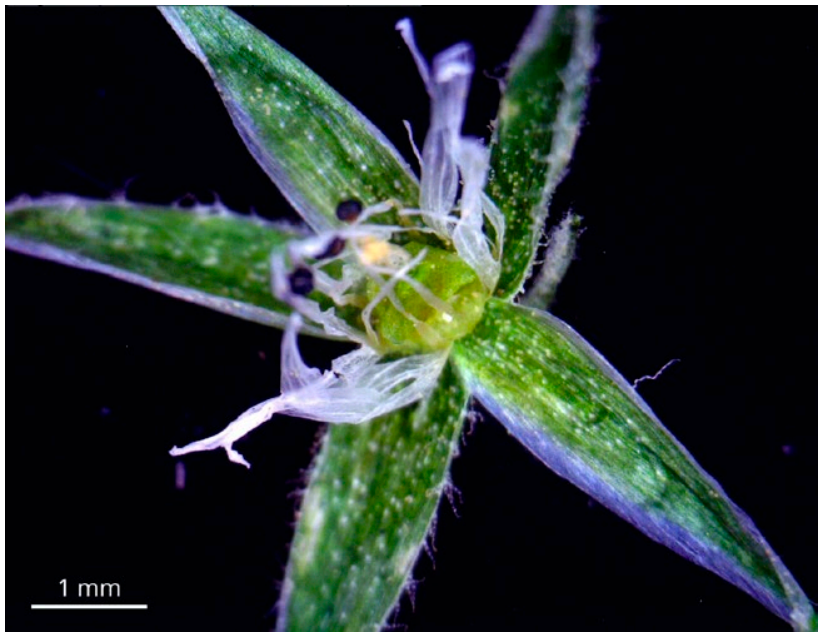

Figure 3. Flower of Stellaria ruderalis from Dmytre village.

nutrient-rich habitat of the alliance Aegopodion podagrariae Tüxen 1967 (Solomakha 2008; Láníková et al. 2009), a vegetation type well known for Lviv (Kucheryvyi et al. 1991). Explored plants of S. ruderalis had dense inflorescences (Figure 2), 4-6(8) stamens, petals significantly shorter than sepals (Figure 3 ), seeds longer than 1 $\mathrm{mm}$ and conical tubercles on the seed surface (Figure 4), which allowed us to clearly distinguish it from $S$. media s.str. and other related taxa. Although we expected to find $S$. ruderalis easily, in all other explored localities only $S$. media s.str. was growing. In our opinion, it supports the fact that $S$. ruderalis is currently still spreading in northern Central Europe including Western Ukraine (Lepší et al. 2019).

This is the first report of $S$. ruderalis for Ukraine. The nearest locations of $S$. ruderalis were reported from Tatabánya city in Hungary (about $590 \mathrm{~km}$ away), Kuchyňa village in Slovakia (about $630 \mathrm{~km}$ away), as well as from Břeclav city (about $620 \mathrm{~km}$ away) and Vranovice village (about $630 \mathrm{~km}$ away) in the Czech Republic (Lepší et al. 2019). Hence, this is the northeasternmost locality of $S$. ruderalis in Europe so far known. Our finding gives a hope that $S$. ruderalis will be soon discovered in other parts of Ukraine as well as other countries of Eastern and Southeastern Europe.

\section{ACKNOWLEDGMENTS}

We would like to thank Tetiana Pachschwöll for her comments which significantly improved the manuscript. A.N. cordially thanks Dr. Tymur Bedernichek, who provided microscopic facilities.

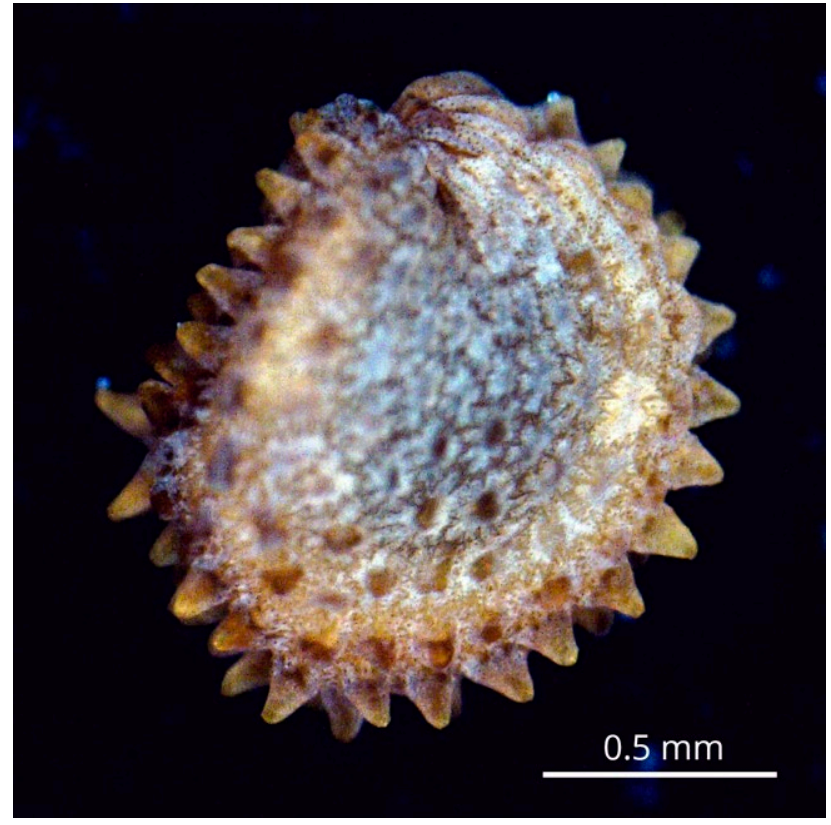

Figure 4. Seed of Stellaria ruderalis from Dmytre village.

\section{REFERENCES}

Chater AO, Heywood VH. 1964. Stellaria L. In: Tutin TG, Heywood VH, Burges NA, Valentine DH, Walters SM, Webb DA, editors. Flora Europaea. Vol. 1. Cambridge University Press, Cambridge; p. 133-136.

Colasante M., Lucchese E., Noris M. 1999. The invasive Stellaria media (L.) Vill. (Caryophyllaceae), a critical taxon at specific and subspecific level. In: Proceedings of the 5 th International Conference on the Ecology of Invasive Alien Plants; October 13-16; La Maddalena, Sardinia, Italy. p. 44-45.

Klokov MV. 1952. [Genus 255. Zirochnyk - Stellaria L.] In: Kotov MI, editor. [Flora of the Ukrainian SSR. Vol. 4]. Kyiv: Publishing house of the Academy of Sciences of the Ukrainian SSR. p. 424-435. Ukrainian.

Kucheryvyi VO, Solomakha VA, Solomakha TD, ShelyahSosonko YR, Kramarets VO. 1991. [Syntaxonomy of ruderal vegetation in Lviv]. Ukr Bot J. 48: 48-54. Ukrainian.

Láníková D, Kočí M, Sádlo J, Šumberová K, Hájková P, Hájek M, Petř́ik P. 2009. Nitrofilní vytrvalá vegetace vlhkých a mezických stanovišt' (Galio-Urticetea). [Nitrophilous perennial vegetation of wet to mesic habitats]. In: Chytrý M, editor. Vegetace České republiky. 2. Ruderální, plevelová, skalní a sutová vegetace [Vegetation of the Czech Republic 2. Ruderal, weed, rock and scree vegetation]. Praha: Aca- 
demia. p. 290-378. [accessed 2020 July 16]. https:// pladias.cz/en/vegetation/description/Aegopodion $\% 20$ podagrariae. Czech and English.

Lepší M, Lepší P, Koutecký P, Lučanová M, Koutecká E, Kaplan Z. 2019. Stellaria ruderalis, a new species in the Stellaria media group from central Europe. Preslia. 91: 391-420. https://doi.org/10.23855/preslia.2019.391

Mosyakin SL, Fedoronchuk MM. 1999. Vascular plants of Ukraine. A nomenclatural checklist. Kyiv: M.G. Kholodny Institute of Botany.

Sobey DG. 1981. Biological flora of the British Isles: Stellaria media (L.) Vill. J Ecol. 69: 311-35. https://doi. org/10.2307/2259833

Solomakha IV. 2008. Syntaxonomy of vegetation of Ukraine. Kyiv: Phytosociocenter. Ukrainian.

Sytschak NN, Kagalo AA. 2010. Addition to the Flora of Lviv region (plain part). Naukovi Osnovy Zberezhennya Biotychnoyi Riznomanitnosti. 1: 173-196. Ukrainian.

Whitehead FH, Sinha RP. 1967. Taxonomy and taximetrics of Stellaria media (L.) Vill., S. neglecta Weihe and S. pallida (Dumort.) Piré. New Phytol. 66: 769-784. https://doi.org/10.1111/j.1469-8137.1967.tb05444.x

Zelenchuk A. 1991. The inventory list of vascular plants of Lviv region. Visnyk L'vivs'kogo Universytetu. Biol Ser. 21: 16-33. Ukrainian. 